\title{
Child abuse in India -A review
}

\author{
Shaik Ali Hassan ${ }^{1 *}$, Sumit Bhateja ${ }^{2}$ \\ ${ }^{1}$ Dental surgeon, ${ }^{2} \mathrm{HOD}$, Dept. of Oral Medicine, ${ }^{1,2}$ Manav Rachna Dental College, Faridabad, Haryana, India
}

\section{*Corresponding Author: Shaik Ali Hassan}

Email: alishaikhassan@gmail.com

\begin{abstract}
Healthy, protected, well-developed population of children will grow up to be most productive in next generation of the country. The essential duty of saving kids from manhandle and disregard lies with the families or the parent. Nonetheless, people group and common society and every single other person are likewise liable for the consideration and security of youngsters. The wounds of child abuse might be distinctive for various kids, be that as it may, a few sorts of wounds are trademark to manhandle. A significant number of these wounds are effectively seen by the dental clinician in the course of routine dental treatment and are inside the extent of dentistry for distinguishing proof.
\end{abstract}

Keywords: Child abuse, Dentistry, Jurisdiction, MCWD.

\section{Introduction}

Child misuse has become a consuming issue in the ongoing years. This maltreatment and viciousness have no geographic and social limits. It is common among the rich and poor people, instructed and uneducated, youthful and middle-aged, and city tenants and provincial people. As per the Journal of Child Abuse and Neglect, child abuse is "any ongoing act or inability to follow up on the part of a parent or guardian which brings about death, genuine physical or passionate damage, sexual misuse or abuse, a demonstration or inability to act which displays a fast approaching danger of risk to child. ${ }^{1}$ Most child abuse happens in a kid's home, with a littler sum happening in the associations, schools or networks the kid connects with. Various jurisdictions have built up their very own meanings of kid maltreatment for the motivations behind expelling a youngster from his/her family as well as arraigning a criminal accusation. The pointers that might be recognizable to the dental expert incorporate injury to the teeth and wounds to the mouth, lips, tongue or cheeks that are not reliable with a mishap. ${ }^{2}$ Other regular indications of youngster misuse incorporate cracks of the maxilla and mandible also, oral consumes. Wounds to the upper lip and maxillary labial frenum might be a trademark in seriously mishandled little youngsters. ${ }^{3}$ When an individual is assaulted out of the blue, the head, neck and facial territories are frequently included. Dental experts are in a special position to recognize potential instances of kid mishandle and disregard. Dental care suppliers are bound to see proof of physical maltreatment than are the other social insurance laborers, as it has been accounted for that orofacial injury is available in roughly $50-75 \%$ of every single detailed instance of physical child abuse. ${ }^{4}$

\section{Prevalance}

Child abuse in India is regularly a hidden wonder, particularly in the event that it occurs at home or by relatives. The association service of ladies and kid improvement (MWCD) discharged an examination report in 2007 which evaluated the frequency of kid misuse nationwide. ${ }^{5}$ Recently an information by the NCRB features the way that there is a $70 \%$ ascent in assault and kidnapping of minors though it has expanded to $40 \%$ in the event that of dissertation. ${ }^{6}$

\section{Risk Factors}

Realized hazard factors for physical abuse are teenage pregnancy, undesirable pregnancy, prematurity, formative issue as well as constant ailment, twin pregnancy, substance misuse, neediness, absence of information on child rearing, youngster wellbeing and improvement $^{7}$ Child qualities are additionally significant in kid misuse counting age, a past history 
of misuse and comorbid conditions having a place with the youngster. About $71 \%$ of kids are manhandled between the ages of 1 and 12. Kids younger than 4 are at the most serious danger of extreme damage, and record for $79 \%$ of youngster abuse fatalities, with newborn children under 1 year representing $44 \%$ of passings. Kids with learning inabilities, lead issue, constant sicknesses, mental retardation, prematurity, or different impairments are at expanded danger of causing misuse. ${ }^{8}$

\section{What has to be reported}

A report of youngster misuse ought to contain the accompanying data, on the off chance that it is known:

1. The names and personal residence of the child and the childs guardians or different people accepted to be liable for the youngster's consideration.

2. The childs present whereabouts

3. The youngster's age

4. Be explicit about the nature and degree of the youngster's wounds, including any proof of past wounds. Portrayal of injury should begin with the size, shape, shading, area, and radiographic depiction (if appropriate) of the damage. Alongside that notice the quantity of wounds present at each site, and if fundamental, sketch the damage and the body part where it is found. In the event that it shows up suspicious, detail the kid's conduct alone just as at the point when they collaborate with their parent

5. The name, age, and state of other kids in the equivalent family unit

6. Whatever other data that you accept might be useful in setting up the reason for the maltreatment to the kid

7. The character of the individual or people liable for the mishandle or disregard to the youngster, whenever known

8. Archive all parts of your meetings with the youngster what's more, parent. Record verbatim the remarks made by the kid and parent clarifying the damage

9. Sign and date the report, and obtain the signature of a witness to the injuries and interviews. ${ }^{9}$

\section{Government Rules}

After the MCWD have a look at on child abuse carried out in 2006, numerous measures had been taken to shield youngsters from violence and abuse and the Integrated Child Protection Scheme is one of them. The MWCD launched a CHILDLINE provider in 1998-1999. The 24-hour toll-unfastened emergency carrier presents assistance to youngsters in need of care and safety. As of March 2013, a complete of 27 million calls have been serviced. It operates in 291 towns/districts in 30 states and Union Territories across India. $^{10}$

In May 2012, India's parliament took a prime step by way of passing the POCSO Act. Under the law, all varieties of toddler sexual abuse are actually specific crook offenses for the first time ever in India. The regulation states that, when a doctor has cause to suspect that a baby has been or is being sexually abused, he/she is required to file this to the appropriate authorities (i.E., the police or the applicable character within his/her enterprise who will then have to file it tothe police). Failure to do so might result in imprisonment of up to six months, without or with first-rate. $^{11}$

In 2014, a bill became handed to amend Juvenile Justice Act which blanketed corporal punishments also as crook offence. ${ }^{12}$ Apart from its domestic legal guidelines, India is a part of some of global human rights treaties, including the International Covenant on Civil and Political Rights and the Convention on the Rights of Child, which provide precise protections for the rights of kids. These regulatory our bodies call for measures to save you and punish abuses by means of government officials and area a burden on governments on the critical and nation tiers to undertake measures to save you and punish abuses by means of private citizens. ${ }^{13}$

\section{Conclusion}

Whenever a dentist sees a child abuse whether in dental clinic or outside he should report that to the legal authorities like police. This has to completely eradicated from the childs life. This article deals with child abuse as this cannot completely stop the abuse but it can keep the abuse under control and creates awareness about the law suit behind this. 


\section{Source of Funding}

None.

\section{Conflict of Interest}

None.

\section{References}

1. Somani R, Kushwaha V, Kumar D, Khaira J. Review paper- Child abuse and its detection in the dental office. $J$ Indian Acad Forensic Med 2011;33:361-5.

2. The prevalence and distribution of bruising in babies. Arch Dis Child 1999;80:363-6

3. Child abuse: Oral manifestations and their recognition by dentists. Rev Odontol UNICID 2003;1:123-8

4. Child abuse: Oral manifestations and their recognition by dentists. Rev Odontol UNICID 2003;1:123-8.

5. Gupta N, Aggarwal NK. Child abuse. Delhi Psychiatr J 2012;15:416-9.

6. Kacker L, Varadan S, Kumar P. Study on child abuse: India 2007. Ministry of Women and Child Development, Government of India. New Delhi, India: Kriti; 2007:7.

7. Risk of injury to children less than 5 years of age in day care versus home care settings. Pediatrics 1989; 84:1011-6

8. Cutaneous signs of child abuse. J Am Acad Dermatol 2007;57:371-92.
9. Shastri P. Children at greater risk of abuse reveals NCRB data. The Times of India; 2014 Jul Children-at-greater-risk-of-abuse-reveals-NCRB-data/ articleshow/37920725.cms [Last accessed on 2015 Oct 10].

10. Model Guidelines under Section 39 of the Protection of Children from Sexual Offences Act, 2012. Ministry of Women And Child Development; 2013: September. Available from: http://wcd.nic.in/sites/default/files/ POCSO-ModelGuidelines.pdf [Last accessed on 2015 Oct 14].

11. Shastri P. Children at greater risk of abuse reveals NCRB data. The Times of India; 2015:9.

12. AnandU. Soon you may land in jail for beating child. New Delhi: The Indian Express; 2014 Aug 3. Available from: http://indianexpress.com/article/ india/india-others/soon-you-may-land-in-jail-for-beating-ch ild/\#sthash. yT1cUa0f.dpuf [Last accessed on 2015 Oct 14].

13. Weidinger DK. Infant \& your health - Dental team's responsibility in reporting child abuse and neglect. Arizona Department of Health Services.

How to cite this article: Hassan SA, S Bhateja. Child abuse in India -A review. $J$ PaediatrNurs Sci 2019;2(4):92-4. 